\title{
Saccharification of Sugarcane Bagasse by Enzymatic Treatment for bioethanol production
}

\author{
Firoz Md. Ahmed ${ }^{1 *}$, Sabita Rezwana Rahman ${ }^{2}$ and Donald James Gomes ${ }^{2}$ \\ ${ }^{1}$ Department of Microbiology, Jahangirnagar University, Savar, Dhaka-1342, Bangladesh \\ ${ }^{2}$ Department of Microbiology, University of Dhaka, Dhaka-1000, Bangladesh \\ E.mail: $\underline{\text { md.firozahmed@hotmail.com }}$
}

Received 1 October 2011; Received in revised form 30 January 2012; Accepted 23 February 2012

\begin{abstract}
Aims: The escalating demands for traditional fossil fuels with unsecured deliverance and issues of climate change compel the researchers to develop alternative fuels like bioethanol. This study examines the prospect of biofuel production from high carbohydrate containing lignocellulosic material, e.g. sugarcane bagasse through biological means. Methodology and Results: Cellulolytic enzymes were collected from the culture filtrate of thermotolerant Trichoderma viride grown on variously pre-treated sugarcane bagasse. CMCase and FPase enzyme activities were determined as a measure of suitable substrate pre-treatment and optimum condition for cellulolytic enzyme production. The highest CMCase and FPase activity was found to be $1.217 \mathrm{U} / \mathrm{ml}$ and $0.109 \mathrm{U} / \mathrm{ml}$ respectively under the production conditions of $200 \mathrm{rpm}, \mathrm{pH} 4.0$ and $50^{\circ} \mathrm{C}$ using steamed $\mathrm{NaOH}$ treated bagasse as substrate. SEM was carried out to compare and confirm the activity of cellulolytic enzymes on sugarcane bagasse. Saccharification of pre-treated bagasse was carried out with crude enzymes together using a two-factor experimental design. Under optimized conditions the pre-treated bagasse was saccharified up to $42.7 \%$ in $24 \mathrm{~h}$. The hydrolysate was concentrated by heating to suitable concentration and then used for fermentation by an indigenous isolate of Saccharomyces cerevisiae. With 50 and $80 \%$ brix containing liquor the concentration of alcohol was $0.579 \%$ and $1.15 \%$ respectively.

Conclusion, significance and impact of study: This is the first report in Bangladesh for the production of cellulosic ethanol using local isolates. Though the rate of alcohol production was very low, a great impetus in this field can maximize the production thereby meet the demand for fuel in future.
\end{abstract}

Keywords: Bioethanol, Bagasse, CMCase, FPase, Scanning electron microscopy (SEM), Degree of saccharification $\left(\mathrm{D}_{\mathrm{o}} \mathrm{S}\right)$, Trichoderma viride, Saccharomyces cerevisiae

\section{INTRODUCTION}

Bioethanol can be planed from raw materials like starch, saccharine or cellulosics (Hill et al., 2006; Solomon et. al., 2007). However the high conversion rate $(1.5-30 \%)$ of sunlight into biomass (Alexander, 1985) linked to high energy content (1.6 barrels of fuel oil energy per ton of sugarcane baggasse) have made sugarcane bagasse a suitable substrate of choice for ethanol production. Bangladesh produces more than 150,000 tons of sugar, 100,000 tons of molasses and 800,000 tons of bagasse per year (Banglapedia, 2006). Rapid growth of the sugarcane plants, climate and soil property making the material easily available and annually renewable. So it can act as a cheap substrate with constant supply as a substrate for bioconversion to fuel ethanol.

Cellulose, hemicellulose and lignin are the key biomass polymers found in sugarcane bagasse consisting about $50,27.5$ and $9.8 \%$ respectively. The rest $11.3 \%$ are cell contents of sugarcane (Kewalramani et. al., 1988). Structural features of cellulose such as the degree of crystallinity, the degree of polymerization, the degree of water swelling, and the surface area, limit accessibility of substrate to enzyme and have been demonstrated (Fan et. al., 1982) to affect the rate of enzymatic hydrolysis of cellulose. Pretreatment methods, which disrupt the highlyordered cellulose structure and the lignin-carbohydrate complex, remove lignin, and increase the surface area accessible to enzymes, promote the hydrolysis, and increase the rate and extent of hydrolysis of cellulose in various lignocellulosic residues (Fan et. al., 1982). The enzymatic hydrolysis of cellulosic materials correlates with the level of cellulose crystallinity (Weimer and

Weston, 1985) and complete enzymatic hydrolysis of the polysaccharides of lignocelluloses requires a concerted action of a complex array of hydrolases including cellulase, xylanase, pectinase, and other side-group cleavage enzymes (Broda et. al., 1996).

Microbial cellulases are the most economic and available sources, because microorganisms can grow on inexpensive media such as agriculture and food industries by-products. The genus Trichoderma, filamentous ascomycetes are widely used in industrial applications because of high secretory capacity and inducible promoting characteristics (Mach and Zeilinger, 2003). Saccharomyces cerevisiae is well known yeast for its 
fermentation capacity (Charoenchai, 1998) and hence can be employed for alcohol production from various sugar containing materials. The conversion of lignocellulosic material into biofuels is complicated and not yet a commercial business, but the trends towards commercialization are evident (Hamelinck et al., 2003). The aim of this study was to consign an approach in Bangladesh in the production of alcohol from cheap lignocellulosic substrate like sugarcane bagasse, taking Trichoderma viride into account as a source of cellulolytic enzymes and Saccharomyces cerevisiae as an appliance for alcohol fermentation from saccharified liquor extracted from enzyme treated bagasse.

\section{MATERIALS AND METHODS}

\section{Microorganisms}

Trichoderma viride isolated from decomposing lignocellulosic materials was used for cellulolytic enzyme production using basal medium described by Copa-Patiño et al. (1993). The medium contained (per liter) $0.6 \mathrm{~g}$ $\mathrm{KH}_{2} \mathrm{PO}_{4}, 0.5 \mathrm{~g} \mathrm{MgSO}{ }_{4} .7 \mathrm{H}_{2} \mathrm{O}, 0.4 \mathrm{~g} \mathrm{~K}_{2} \mathrm{HPO}_{4}, 0.74 \mathrm{~g}$ $\mathrm{CaCl}_{2} .2 \mathrm{H}_{2} \mathrm{O}, 2.32 \mathrm{~g} \mathrm{NH}_{4} \mathrm{H}_{2} \mathrm{PO}_{4}$, and $1.0 \mathrm{~g}$ yeast extract, and $7.0 \mathrm{ml}$ of trace salts solution (per $100 \mathrm{ml}, 200 \mathrm{mg}$ $\mathrm{CoCl} .7 \mathrm{H}_{2} \mathrm{O}, 500 \mathrm{mg} \mathrm{FeSO} 4.7 \mathrm{H}_{2} \mathrm{O}, 160 \mathrm{mg} \mathrm{MnSO}{ }_{4} . \mathrm{H}_{2} \mathrm{O}$, and $140 \mathrm{mg} \mathrm{ZnSO}_{4} .7 \mathrm{H}_{2} \mathrm{O}$ ) and Sugarcane bagasse $2.0 \%$ $(\mathrm{w} / \mathrm{v})$ as a carbon source.

\section{Pretreatment of substrate}

A number of physical and chemical pretreatments of sugarcane bagasse were performed in an effort to improve the substrates for the extracellular enzyme production as well as for enzymatic saccharifications. The physical treatments included chopping, milling and boiling, while the chemical treatments were done using alkali, acid, peroxide or solvent. In later case with alkali treatment milled bagasse was kept at $85^{\circ} \mathrm{C}$ for $1 \mathrm{~h}$ in $2 \%$ $\mathrm{NaOH}$ (solid liquid ratio was 1:4). Acid treatment was done with $\mathrm{H}_{2} \mathrm{SO}_{4}$ where chopped bagasse was heated at $100{ }^{\circ} \mathrm{C}$ for $30 \mathrm{~min}$ with $10 \%$ sulphuric acid solution (solid liquid ratio was 1:10) (Detroy et al., 1981; Lynd et al., 1987). For peroxide treatment, chopped bagasse was suspended in $5 \%$ hydrogen peroxide (in 1:10 ratio) and kept in room temperature for $1 \mathrm{~h}$. However for solvent treatment chopped bagasse was suspended in aqueous butanol $(50 \% \mathrm{v} / \mathrm{v})$ in the presence of a $0.005 \%$ aluminium chloride catalyst and heated at $121^{\circ} \mathrm{C}$ for $1 \mathrm{~h}$. In each chemical treatment the solid substrate was washed to neutral $\mathrm{pH}$ and dried in the oven at $70{ }^{\circ} \mathrm{C}$ until a constant weight. Both treated $\left(\mathrm{NaOH}, \mathrm{H}_{2} \mathrm{SO}_{4}, \mathrm{H}_{2} \mathrm{O}_{2}\right.$, butanol and boiling) and non-treated chopped bagasse were further passed with steam treatment $\left(121^{\circ} \mathrm{C}\right.$ for 15 min in an autoclave). These substrates were used for enzyme production.

\section{Fungal inoculum preparation}

A suspension of $10^{6}-10^{7}$ spores per $\mathrm{ml}$ (as determined by Neubauer counting chamber) was prepared by scraping conidiospores from agar slants into sterile saline water. Two milliliter of the suspension was pipetted into $50 \mathrm{ml}$ of inoculum growth medium (Zhang and WeiMin, 2008) and incubated in an orbital shaking incubator at $30^{\circ} \mathrm{C}$ and 200 $\mathrm{rpm}$. After $36 \mathrm{~h}$ growth, the medium was used as the inoculum for enzyme production.

\section{Culture conditions and enzyme production}

The standard basal medium used for growth and enzyme production was described by Copa-Patiño et al. (1993). The initial $\mathrm{pH}$ was adjusted to 5.0. Cultures were conducted in $250 \mathrm{ml}$-Erlenmeyer flasks containing $100 \mathrm{ml}$ basal medium and $2 \%(\mathrm{w} / \mathrm{v})$ sugarcane bagasse (pretreated) as a carbon source. The growth medium was sterilized at $121{ }^{\circ} \mathrm{C}$ for $15 \mathrm{~min}$, then inoculated with $5 \mathrm{ml}$ spore suspension $\left(10^{6}-10^{7}\right.$ spores) and incubated at 30 ${ }^{\circ} \mathrm{C}$ on an orbital shaking incubator at $200 \mathrm{rpm}$ for 3 days. After cultivation the culture filtrate was centrifuged at $10,000 \mathrm{rpm}$ for $15 \mathrm{~min}$ using lab centrifuge. The clear supernatant fluid was used directly for the determination of the enzyme activities.

\section{Chemical analysis}

Reducing sugar in the wart and ferments was determined by dinitrosalicylic acid (DNS) method (Miller, 1959) using glucose as standard. Both pretreated and native sugarcane bagasse was analyzed for their total carbohydrate content using a two-stage hydrolysis method essentially according to Wilke et al. (1981).

\section{Enzyme assays}

Filter paper activity (FPase) was determined essentially according to the IUPAC instructions (Ghose, 1987), and the liberated reducing sugars were estimated by the DNS method (Miller, 1959). FPase activity corresponds to $1 \mu M$ of reducing sugars as glucose equivalents librated per min under the assay conditions. Carboxymethycellulase (CMCase) activity was estimated essentially according to IUPAC instructions (Ghose, 1987) using $1 \%$ solution of carboxymethyl cellulose-sodium salt (in $0.05 \mathrm{M}$ citrate buffer, $\mathrm{pH}$ 5.0) as substrate. One CMCase unit is the amount of enzyme necessary to produce $1 \mu \mathrm{M}$ reducing sugar as glucose equivalents per min under the standard assay conditions. The assay was also carried out for different time intervals to find out the optimum time for enzyme activity.

\section{Saccharification of sugarcane bagasse}

Saccharificaiton experiment was performed in $100 \mathrm{ml}$ Erlenmayer flasks with $200 \mathrm{mg} \mathrm{(2 \%} \mathrm{dry} \mathrm{wt)} \mathrm{substrate} \mathrm{and}$ $10 \mathrm{ml}$ enzyme solution in citrate buffer $(0.05 \mathrm{M}, \mathrm{pH} 5.0)$. The reaction mixture was sealed and incubated at $50{ }^{\circ} \mathrm{C}$ under continuous agitation (150 rpm) for $48 \mathrm{~h}$. Hydrolysates were transferred in screw-capped tubes, heated in a boiling water bath for $15 \mathrm{~min}$ and centrifuged to remove solid particles. The supernatant were used for analysis of released sugars. Saccharifcation study was 
carried out at various temperatures and also at various $\mathrm{pHs}$ to find out the best hydrolysis preparation. Sugar released was estimated by DNS method (Miller, 1959) and Degree of saccharifcation $\left(D_{0} S\right)$ was calculated essentially described by Vallander \& Eriksson (Vallander and Eriksson, 1985) using the following formula:

$$
D_{\circ} S=\frac{c \times v \times f_{1}}{m \times f_{2}} \times 100
$$

Where $c$ is the sugar concentration in the hydrolysate estimated as total reducing sugars, in $\mathrm{mg} / \mathrm{ml} ; v$ is the liquid volume $(\mathrm{ml})$ of the hydrolysates, $f_{1}$ is the factor $(0.90$ for hexoses) used to convert monosaccharide to polysaccharide due to water uptake during hydrolysis; $m$ is the amount of initial substrate $(\mathrm{mg})$ dry weight, and $f_{2}$ is the factor for the carbohydrate content of the substrate (total carbohydrate, $\mathrm{mg} /$ total substrate, $\mathrm{mg}$ ).

\section{Statistical optimization of saccharification conditions}

The optimum temperature and $\mathrm{pH}$ for saccharification of sugarcane bagasse was finally determined using a central composite design. A two-factor experimental design was used; each factor was studied at three levels. The optima were calculated according to Retzlaff et al. (1975).

\section{Sachharification kinetic studies}

The saccharification experiments were carried out for $48 \mathrm{~h}$ and reducing sugar was estimated at various time intervals. Initially the reaction mixture contained $2 \%$ of substrate that was incubated under optimized conditions. The degree of saccharification was plotted against time to evaluate time-dependent enzymatic hydrolysis of sugarcane bagasse.

\section{Processing of the saccharified liquor for fermentation}

Prior to fermentation the saccharified liquor was separated from the solid substrate. A refractometer was used to determine the percentage of sugar in that liquor. The liquid was boiled to reduce the volume until the sugar concentration reaches $80 \%$ in the refractometer scale. The liquid was filtered to remove the impurities and used in the fermentation medium as substrate for ethanol production by yeast isolate.

Preparation of yeast inoculum for ethanol fermentation

One $\mathrm{ml}$ of yeast cell suspension (about $10^{8}$ viable cells, determined using a Neubauer counting chamber) was inoculated to $100 \mathrm{ml}$ MYGP broth in $500 \mathrm{ml}$-conical flask and incubated at $30^{\circ} \mathrm{C}$ on a rotary shaker for $24 \mathrm{~h}$. The standard concentration of the inoculum $\left(1.5 \times 10^{8} \mathrm{cells} / \mathrm{ml}\right)$ was prepared by the properly diluting the suspension with sterile distilled water.

\section{Fermentation process}

Ethanol production was carried out in batch culture using various concentrations of the clarified liquor obtained from sugarcane bagasse. Malt extract $(0.3 \%)$, yeast extract $(0.3 \%)$ and peptone $(0.5 \%)$ was added to the liquor and final $\mathrm{pH}$ was set to 5.5 . One milliliter of yeast inoculum was inoculated to $100 \mathrm{ml}$ of the broth in $250 \mathrm{ml}$ conical flask and was incubated at $30^{\circ} \mathrm{C}$ for $72 \mathrm{~h}$.

\section{Estimation of ethanol}

Ethanol produced in the fermentation medium was estimated by potassium dichromate oxidation method (Kumnuanta, 1983). Potassium dichromate (33.882 g/l), ferrous ammonium sulphate $(135.5 \mathrm{~g} / \mathrm{l})$ and diphenylamine $\left(0.5 \mathrm{~g} / 100 \mathrm{ml}\right.$ concentrated $\left.\mathrm{H}_{2} \mathrm{SO}_{4}\right)$ solutions were used as reagent for estimation of ethanol concentration. The fermented sample was diluted ten times with distilled water. Ten millilitre of the diluted sample was distilled against $\mathrm{K}_{2} \mathrm{Cr}_{2} \mathrm{O}_{7}(10 \mathrm{ml})$ containing concentrated $\mathrm{H}_{2} \mathrm{SO}_{4}$ $(5-6 \mathrm{ml})$. Then distilled was titrated against freshly prepared ferrous ammonium sulphate solution with diphenylamine as an indicator. Appearance of green colour indicated the end point of the titration. Burette reading (amount ferrous ammonium sulphate) was recorded to calculate the amount (in percentage) of ethanol present in the sample.

\section{RESULTS AND DISCUSSION}

The development of a remunerative process to convert low value biomass like sugarcane bagasse to high value product like ethanol requires several key steps, especially cellulase production, be optimized (Eveleigh, 1987). The structural complexity are often easily degraded by xylanases, mannanases etc. which are present in some cellulase preparations, so that their presence may actually lead to increased production of reducing sugars and greater susceptibility of the residual cellulose (Tolan and Finn, 1987). Figure 1 shows various types of hydrolytic enzymes that were found in this experiment by growing Trichoderma viride on relevant media.

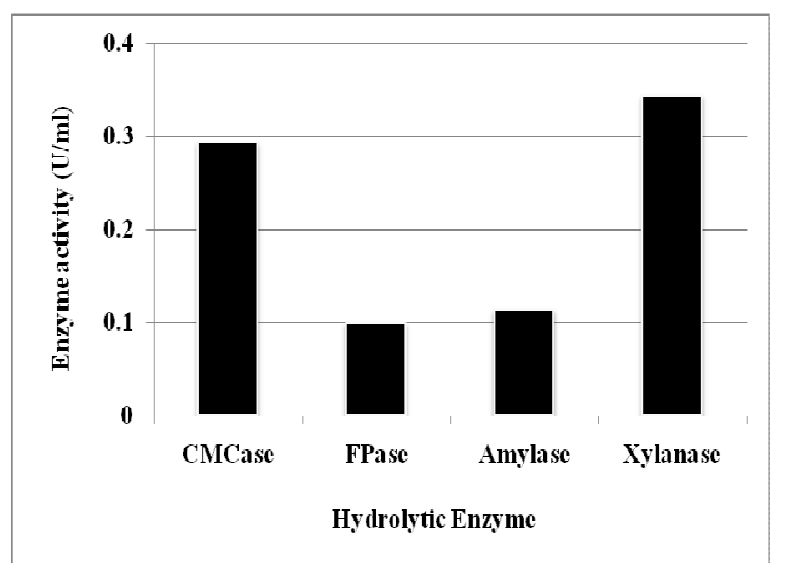

Figure 1: Production of various hydrolytic enzymes by Trichoderma viride 
Trichoderma viride was grown on both treated and untreated bagasse as substrate for cellulase enzyme production. With $\mathrm{NaOH}, \mathrm{H}_{2} \mathrm{SO}_{4}$ or $\mathrm{H}_{2} \mathrm{O}_{2}$ treated bagasse an enhanced fungal attack on the substrate was noticed. $\mathrm{NaOH}$ is thought to have some saponification activity on bagasee (Fan et al., 1981), $\mathrm{H}_{2} \mathrm{SO}_{4}$ removes hemicellulose extensively while oxidizing agent i.e., $\mathrm{H}_{2} \mathrm{O}_{2}$ causes chemical oxidation of lignin and remove it (Fan et al., 1981). Chemical pretreatment with solvents like butanol was found to be inefficient. The accessibility of the chemically pretreated bagasse to the fungal attack was enhanced remarkably by additional steam treatment, as was also reported by Saddler et al. (1982). Chemical pretreatment with alkali (caustic soda) appeared to be most effective in enhancing the extent of subsequent enzymatic hydrolysis. Similar findings have been reported for alkali pretreatments of various lignocellulosic substrates (Fan et al., 1981). The highest CMCase activity $(0.293 \mathrm{U} / \mathrm{ml})$ was obtained from steamed $\mathrm{NaOH}$ treated (short piece) bagasse, followed by steamed $\mathrm{H}_{2} \mathrm{SO}_{4}$ substrate $(0.285 \mathrm{U} / \mathrm{ml})$ and steamed $\mathrm{H}_{2} \mathrm{O}_{2}$ treated substrate $(0.283 \mathrm{U} / \mathrm{ml})$. The highest FPase activity $(0.099$ $\mathrm{U} / \mathrm{ml}$ ) was found from steamed $\mathrm{NaOH}$-treated (short piece) bagasse. It was followed by steamed $\mathrm{H}_{2} \mathrm{O}_{2}$ substrate $(0.089 \mathrm{U} / \mathrm{ml}$ FPase $)$ and steamed $\mathrm{H}_{2} \mathrm{SO}_{4}$ treated substrate $(0.084 \mathrm{U} / \mathrm{ml}$ FPase $)$. The enzyme activities were almost constant during storage at $4{ }^{\circ} \mathrm{C}$ refrigerator upto 2 weeks (Figure 2).

a)

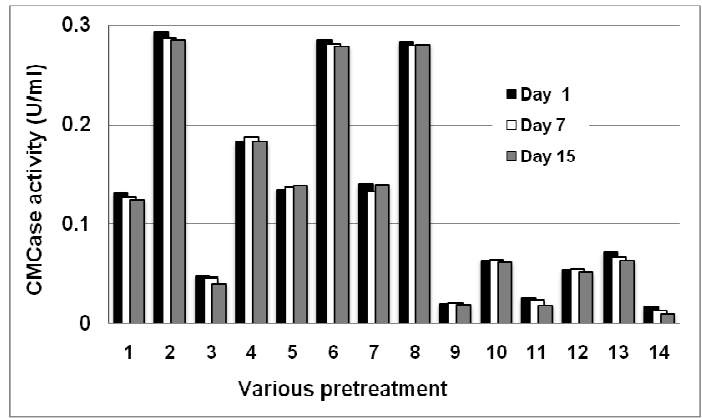

b)

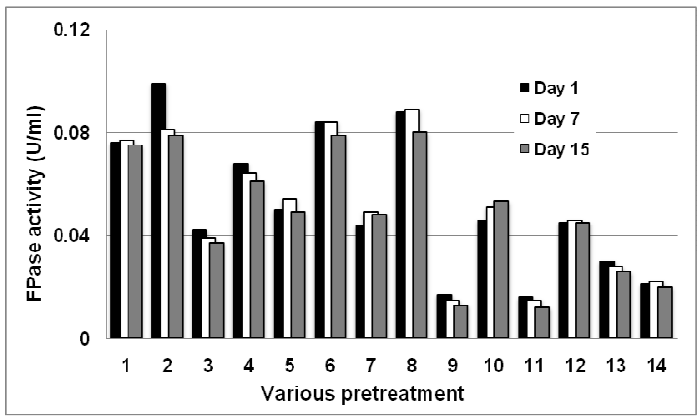

Figure 2: Effect of different pretreatments of sugarcane bagasse on extracellular (a) CMCase, (b) FPase production by Trichoderma viride in shake-flask culture (1. $\mathrm{NaOH}$ treated short pieces bagasse, 2. $\mathrm{NaOH}+$ steam treated short pieces bagasse, $3 . \mathrm{NaOH}$ treated ground bagasse, 4. $\mathrm{NaOH}+$ steam treated ground bagasse, 5 . $\mathrm{H}_{2} \mathrm{SO}_{4}$ treated short pieces bagasse, $6 . \mathrm{H}_{2} \mathrm{SO}_{4}+$ steam treated short pieces bagasse, $7 . \mathrm{H}_{2} \mathrm{O}_{2}$ treated short pieces bagasse, $8 . \mathrm{H}_{2} \mathrm{O}_{2}+$ steam treated short pieces bagasse, 9. Butanol treated short pieces bagasse, 10. Butanol +steam treated short pieces bagasse, 11. Boiled short pieces bagasse,12. Boil + steam treated short pieces bagasse, 13. Short pieces bagasse, \& 14. Steam treated short pieces bagasse)
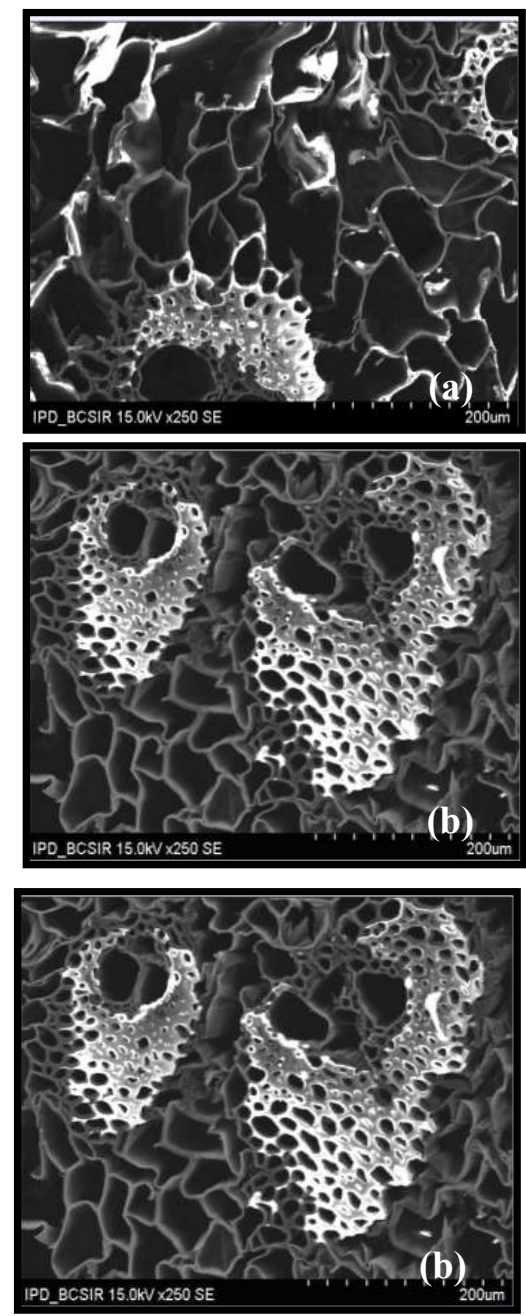

Figure 3: Scanning electron microscopy of sugarcane bagasse cross section- (a) untreated; (b) alkali-treated; (c) enzyme-treated bagasse

However, the cellulase yields of this study by $T$. viride were relatively inferior as compared to experiment of Thomas et al. (1981) and Acebal et al. (1986). The highest endoglucanase (CMCase) was found to be 1.217 $\mathrm{U} / \mathrm{ml}$ in this study, while a 10 -fold higher activity was reported by Acebal et al. (1986) with T. reesei QM 9414. 
Again, the FPase activity by $T$. viride in this study was $0.109 \mathrm{U} / \mathrm{ml}$, which was considerably lower than that reported for $T$. reesei QM $9414(0.34 \mathrm{U} / \mathrm{ml})$ (Thomas et al., 1981). Biosynthesis of hydrolytic enzymes on lignocellulosics depends on multiple factors. Saccharification syrups contain not only glucose and cellobiose but also other sugars, like as xylose (Palmer, 1975). Cellulase is moderately inhibited by glucose and strongly inhibited by cellobiose (Mandels et al., 1978). For both sugars the extent of inhibition increases with increasing resistance of the cellulose. Cellobiase is competitively inhibited by glucose (Gong et al., 1977; Bissett et al., 1978).

Scanning Electron Microscopy (SEM) of untreated, alkalitreated and enzyme treated bagasse were taken and compared to find out what actually happens with $\mathrm{NaOH}$ treatment and what changes do crude enzyme introduces to sugarcane bagasse. All samples were coated with platinum and magnification of $x 250$ was used. Figure 3(a) shows the electron micrograph of cross section of untreated bagasse. It shows large void and loose packing of the fibres. The wall of untreated fibres was intact. Figure 3(b) shows the SEM of alkali-treated fibre where the cell wall still looks normal, and no rupture or splitting was observed as a resulting of alkali treatment however, packing of the fibres was partially loosened. Figure 3(c) shows the cross section of enzyme treated bagasse where sponge-like structures of the bagasse is evident and the structure of the lignocellulosic biomass surface appears to be more fragile.

The extent of hydrolysis depended on the reaction temperature and maximum hydrolysis was achieved at 50 ${ }^{\circ} \mathrm{C}$ (Figure 4). Above and below of this temperature the degree of saccharification $\left(D_{\circ} S\right)$ was reduced considerably. The $D_{0} S$ of steamed alkali-treated chopped bagasse by the crude enzyme preparation from $T$. viride was $38.8 \%$, while the untreated bagasse was saccharified to $25.6 \%$. With the increasing temperature the $D_{0} S$ of untreated and alkali-treated bagasse were reduced and at $70{ }^{\circ} \mathrm{C}$ the values were only $6 \%$ and $8 \%$ respectively. Increased susceptibility of lignocellulosics by alkali pretreatment might be due to removal of lignin seal and swelling of the substrates in an alkaline condition, which might increase accessibility of the substrate to enzymatic attack (Fan et al., 1981).

The pretreated substrate was substantially hydrolyzed over a pH range between 4.0 and 6.0. A two-factor central composite design was employed to confirm the optimum $\mathrm{pH}$ and temperature for hydrolysis of treated bagasse by the enzyme of $T$. viride. Highest saccarification value was observed at $\mathrm{pH} 5.0$ and $50{ }^{\circ} \mathrm{C}$ that corresponded to the DoS value of $42.75 \%$ (Figure 5 ).

Time course of enzymatic saccharification of alkali treated bagasse showed rapid initial increase of reducing sugar concentration (up to $8 \mathrm{~h}$ ) and the rate of this increase was substantially reduced at later stages. The substrate was saccharified up to about $24.0 \%$ within $8 \mathrm{~h}$ hydrolysis time and after $24 \mathrm{~h}$, the degree of saccharification was increased to about $33.5 \%$. Further increase of the hydrolysis time from $24 \mathrm{~h}$ to $48 \mathrm{~h}$, the subsequent increase of the extent of hydrolysis was only about $9.0 \%$ (Figure 6).

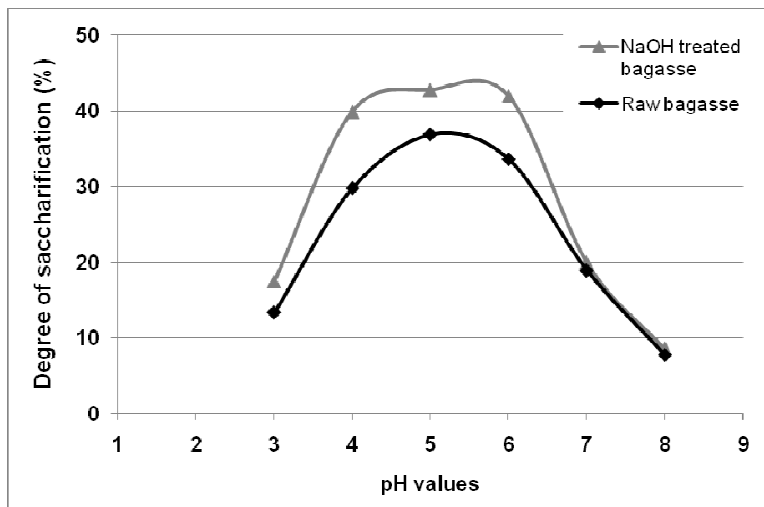

Figure 5: Effect of $\mathrm{pH}$ on enzymatic saccharification of sugarcane bagasse

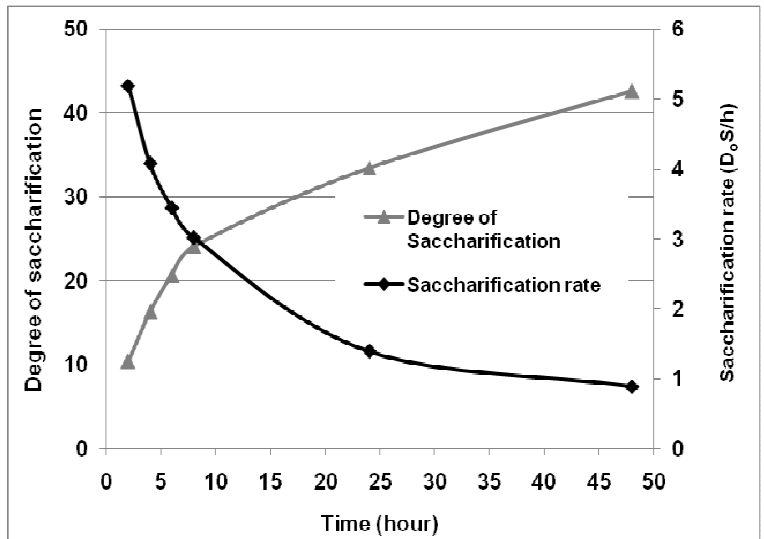

Figure 6: Time course of enzymatic saccharification of alkali pretreated bagasse by crude enzyme preparation of Trichoderma viride

The yeast Saccharomyces sp. is the choice of organisms due to its high ethanol production efficiency than others (Jones et al., 1981). The initial sugar concentration of the fermentation medium is an important factor since too much sugar results in lower ethanol production (Jones et al., 1981; Beuchat, 1983). The organism utilizes hexose sugars; however it is unable to utilize xylose (Jeffries, 1990). The yeast isolate used in this experiment was selected for higher alcohol productivity on pure glucose and molasses. But the organism was not very efficient in utilizing the saccharified liquor extracted from enzymatic hydrolysis of bagasse. With $80 \%$ and $50 \%$ brix containing liquor the concentration of alcohol was $1.15 \%$ $(\mathrm{v} / \mathrm{v})$ and $0.579 \%(\mathrm{v} / \mathrm{v})$ respectively; those were very low as compared to the amount found by Tang et al. (2008) 
with Saccharomyces cereviseae strain KF-7. Since the saccharification study was carried out by enzymes extracted from fungal growth medium and later on the saccharified liquor was used for fermentation, some fungal proteins might be left on the preparation affecting the growth of fermenting yeast negatively. Again, though $S$. cerevisiae is one of the most prominent ethanol producing organisms using hexose sugars, it is unable to utilize xylose (Jeffries, 1990). As in this experiment a high xylanase activity was found in the crude enzyme extract, it can be said that a substantial amount of xylose might be present in the saccharified liquor which affected the rate of fermentation.

In recent years, engineered yeasts have been described efficiently fermenting xylose (Ohgre et al., 2006; Brat et al., 2009) and arabinose (Becker and Boles, 2003) and even both together (Karhumaa et al., 2006). Besides Saccharomyces cerevisiae, microorganisms such as Zymomonas mobilis and Escherichia coli have been targeted through metabolic engineering for cellulosic ethanol production.

\section{CONCLUSION}

The choice of lignocellulosic materials like sugarcane bagasse for bioethanol production has become a recent interest (Sun and Cheng, 2002) however, in Bangladesh this is the first reported experimental work regarding cellulosic ethanol. This experiment was designed to evaluate the possibility of alcohol production from sugarcane bagasse using local fungal and yeast isolates. Our study suggests that $T$. viride is potentially useful for the production of various cellulolytic enzymes. Though, the amount of alcohol obtained was not satisfactory with the isolated Saccharomyces sp., additional work on purification of enzyme from hydrolysis media and separation of sugars from saccharified liqour for the preparation of fermentation media can enhance the production of alcohol. Further experiment may be designed using other cellulosic substances like rice straw, wheat straw, or switch grass as a substrate for bioethanol production. Besides, study can be planed to isolate yeast with improved fermentation capacity. This will ultimately uphold the promise of producing adequate amount of alcohol from given amount of substrate industrially thereby meet the demand for fuel in near future.

\section{ACKNOWLEDGEMENTS}

The authors wish to thank Bangladesh Jute Research Institute, Dhaka for helping in this research.

\section{REFERENCES}

Acebal, C., Castillon, M. P., Estrada, P., Mata, I., Costa, E., Aguado, J., Romero, D. and Jimenez, F. (1986). Enhanced cellulose production from Trichoderma ressei Q M 9414 on physically treated wheat straw. Applied Microbiology and Biotechnology 24, 218-223.
Alexander, A. G. (1985). The Energy Cane Alternative, Sugar Series No. 6. Elsevier, Amsterdam. pp 509.

Banglapedia. (2006). Available at: http://banglapedia.net/HT/G 0045.HTM. [Accessed 13 January 2009].

Becker, J. and Boles, E. (2003). A modified Saccharomyces cerevisiae strain that consumes LArabinose and produces ethanol. Applied Environmental Microbiology 69(7), 4144-4150.

Beuchat, L. R. (1983). Influence of water activity on growth, metabolic activities and survival of yeasts and molds. Journal of Food Protection. 46, 135-141.

Bissett, F. and Sternberg, D. (1978). Immobilization of Aspergillus $\beta$-glucosidase on chitosan. Applied Environmental Microbiology 35, 750-755.

Brat, D., Boles E. and Wiedemann, B. (2009). Functional expression of a bacterial xylose isomerase in Saccharomyces cerevisiae. Applied Environmental Microbiology 75, 2304-2311.

Broda, P., Birch, P. R. J., Brooks, P. R. and Sims, P. F. G. (1996). Lignocellulose degradation by Phanerochaete chrysosporium: Gene families and gene expression for a complex process. Molecular Microbiology 19, 923-932.

Charoenchai, C., Fleet, G. H. and Henschke, P. A. (1998). Effects of temperature, $\mathrm{pH}$, and sugar concentration on the growth rates and cell biomass of wine yeasts. American Journal of Enology and Viticulture 49, 283-288.

Copa-Patiňo, J. L., Kim, Y.G. and Broda, P. (1993). Production and initial characterisation of the xylandegrading system of Phanerochaete chrysosporium. Applied Microbiology and Biotechnology 40, 69-76.

Detroy, R. W., Lindenfelser, L. A., Sommer, S. and Orton, W. L. (1981). Bioconversion of wheat straw to ethanol: Chemical modification, enzymatic hydrolysis, and fermentation. Biotechnology and Bioengineering 23, 1527-1335.

Eveleigh, D.E. (1987). Cellulases: A Perspective. Philosophical Transactions of the Royal Society A321, 435-447.

Fan, L. T., Young-Hyun, L. and Gharpuray, M. M. (1982). The nature of lignocellulosics and their pretreatments for enzymatic hydrolysis. Advances in Biochemical Engineering 23, 157-187.

Fan, L.T., Gharpuray, M. M. and Young-Hyun, L. (1981). Evaluation of Pretreatments for Enzymatic Conversion of Agricultural Residues. Biotechnology and Bioengineering Symposium 11, 29-45.

Ghose, T. K. (1987). Determination of cellulases. Pure and Applied Chemistry 59, 257-268.

Gong, C. S., Ladisch, M. R. and Tsao, G. T. (1977). Cellobiase from Trichoderma viride: purification, kinetics and mechanism. Biotechnology and Bioengineering 19, 959-981.

Hamelinck, C.N., Faaij, A. P. C., Uil, H. and Boerrigter, H. (2003). Production of FT transportation fuels from biomass; technical options, process analysis and optimisation, and development potential, Energy 
research Centre of the Netherlands (ECN), Utrecht University, ISBN: 90-393-3342-4.

Hill, J., Nelson, E., Tilman, D., Polasky, S. and Tiffany, D. (2006). Environmental, economic, and energetic costs and benefits of biodiesel and ethanol biofuels. Proceedings of the National Academy of Sciences 103, 11206-11210.

Jeffries, T. W. (1990). Fermentation of D-xylose and cellobiose. In: Verachert H, De Mot R, editors. Yeastbiotechnology and biocatalysis. Marcel Dekker, New York.

Jones, R., Pamment, P. N. and Greenfied, P.F. (1981). Alcoholic fermentation by yeasts. The effect of environment and other variables. Process Biochemistry 16, 42-49.

Karhumaa, K., Wiedemann, B., Hahn-Hagerdal, B., Boles, E. and Gorwa-Grauslund, M.F. (2006). Coutilization of L-arabinose and D-xylose by laboratory and industrial Saccharomyces cerevisiae strains. Microbial Cell Factories 10, 5:18.

Kewalramani, N., Kamra, D. N., Lall, D. and Pathak, N. N. (1988). Bioconversion of sugarcane bagasse with white rot fungi. Biotechnology Letters 10, 369-372.

Kumnuanta, I., Karuwana, P., Tammarte, P., Komagata, K. and Taguchi, H. (1983). Some problems in local alcohol fermentation in Thailand. Microbial Utilization Renewable Resource 3, 245-253.

Lynd, L. R., Wolkin, R. H. and Grethlein, H. E. (1987). Continuous fermentation of pretreated hardwood and avicel by Clostridium thermocellum. Biotechnology \& Bioengineering Symposium 17, 265- 274.

Mach, R. L., and Zeilinger, S. (2003). Regulation of gene expression in industrial fungi: Trichoderma spp. Applied Microbiology and Biotechnology, 60, 515522.

Mandels, M., Dorval, S. and Mederios, J. (1978). Annual Symposium on fuel from Biomass (Shuster, W.W., ed.) John Wiley and Sons, New York. 2, 627-669.

Miller, G. L. (1959). Use of dinitrosalisylic acid reagent for determination of reducing sugar. Analytical Chemistry 31, 426-428.

Ohgren, K., Bengtsson, O., Gorwa-Grauslund, M. F., Galbe, M. Hahn-Hagerdal, B. and Zacchi, G. (2006). Simultaneous saccharification and cofermentation of glucose and xylose in steampretreated corn stover at high fiber content with Saccharomyces cerevisiae TMB3400. Journal of Biotechnology 126(4), 488-498.

Palmer, J. K. (1975). Liquid chromatography for monitoring the conversion of cellulosic wastes to sugars. Applied polymer symposium 28, 237-245.

Retzlaff, G., Rust, G. and Waibel, J. (1975). Die Bestimmung Optimaler Verhaltisse. In Statistiche Versuchsplanung: Planung Naturwissengschafticher Experimente Und Ihre Auswetung Mit Statisschen Methoden, Hans Richarz Publications-Service, Sankt Augustin. 141-155.

Saddler, J. N., Brownell, H. H., Clermont, L. P. and Levitin, N. (1982). Enzymatic hydrolysis of cellulose and various pretreated wood fractions. Biotechnology and Bioengineering 24, 1389-1402.

Solomon, B. D., Barnes, J. R. and Halvorsen, K. E. (2007). Grain and cellulosic ethanol: History, economics, and energy policy. Biomass and Bioenergy 6, 416-425.

Sun, Y., and Cheng, J. (2002). Hydrolysis of lignocellulosic materials for ethanol production: a review, Bioresource Technology 83, 1-11.

Tang, Y. Q., Kokie, Y., Liu, K., An, M. Z., Morimura, S. and Kida, X. L. Wu. K. (2008). Ethanol production from kitchen waste using the flocculating yeast Saccharomyces cerevisiae strain KF-7. Biomass and Bioenergy 32(11), 1037-1045.

Thomas, K. Ng., and Zeikus, J. G. (1981). Comparison of Extracellular Cellulase Activities of Clostridium thermocellum LQRI and Trichoderma reesei QM9414, Applied Environmental Microbiology 42(2), 231-240.

Tolan, J. S., and Finn, P. K. (1987). Fermentation of Dxylose and L-arabinose to ethanol by Erwinia chrysanthemi. Applied Environmental Microbiology 53, 2033-2038.

Vallander, L., and Eriksson, K. E. L. (1985). Enzymatic saccharification of pretreated wheat straw. Biotechnology and Bioengineering 27, 650-659.

Weimer, P., and Weston, W. (1985). Relationship between the fine structure of native cellulose and cellulose degradability by the cellulase complexes of $T$. reesei and Clostridium thermocellum. Biotechnology and Bioengineering 27, 1540-1547.

Wilke, C.R., Yong, R. D., Sciamanna, A. F. and Freitas, R.P. (1981). Raw materials ecaluation and process development studies for conversion of biomass to sugars and ethanol. Biotechnology and Bioengineering 23, 163-183.

Zhang, Q., and WeiMin. C. (2008). Enzymatic hydrolysis of alkali-pretreated rice straw by Trichoderma reesei ZM4-F3. Biomass and Bioenergy, 32 (12), 1130 1135. 